Петров А. Литературная Россия. Взгляд из Сербии. Белград, 2015. 360 с.

A.G. Sheshken (Moscow, Russia)

\title{
A. Petrov Literary Russia. A Look from Serbia. Belgrade, 2015. 360 p.
}

Труд А. Петрова «Литературная Россия. Взгляд из Сербии» опубликован издательством филологического факультета Белградского университета в рамках исследовательского проекта Библиотека «Язык и литература», которая издается под покровительством президента Республики Сербия и при поддержке Министерства культуры и информации Республики Сербия. Это десятая книга серии «Труды о литературе и языке», где представлены работы сербских и русских ученых по проблемам лингвистики и литературоведения. Серия публикуется на русском языке, что существенно расширяет возможность знакомства с результатами исследований ученых специалистами из других стран, в первую очередь, из России. Таким образом, популяризируются достижения сербской филологии последних десятилетий.

Книга Александра Петрова «Литературная Россия. Взгляд из Сербии» является уникальной по жанру, богатству фактов и подаче материала. Ее автор принадлежит к числу признанных в мире авторитетов в области русской поэзии и до недавнего времени был известен в России прежде всего как переводчик русской лирики и сербский поэт. Такую его репутацию подтверждают многочисленные литературные премии и переводы его стихов во многих странах мира, отклики о его поэзии авторитетов (И. Бродский). Глубокое понимание и восприятие звучания русского поэтического слова, русской литературы и культуры в целом А. Петров впитал с молоком матери. Он по происхождению русский, родился в родовитой дворянской семье (1938) в Королевстве Югославия. Там он вырос и получил образование. А. Петров закончил филологический факультет Белградского университета, где его наставниками были выдающиеся русские и сербские ученые и педагоги (К.Ф. Тарановский), сформировавшие его интерес к научному исследованию в области поэзии. Диссертация на звание доктора филологии была посвящена лирике одного из крупнейших сербских писателей XX в. М. Црнянского («Значение поэзии Милоша Црнянского в эволюции сербского поэтического творчества», 1971). На рубеже 1960-1970-х гг., во время бурных споров о путях развития национальной литературы, А. Петров заявил о себе и как писатель, литературный критик и эссеист. Он был активным участником литературного процесса Сербии: вдохновитель и организатор литературных журналов («Литературная история» / 
«Књижевна историја», 1968-1972), член редколлегий влиятельных литературных изданий («Литературная газета» / «Књижевне новине», 1965-1967), автор литературной рубрики центральной белградской газеты «Политика» (1975-1980), руководитель Союза писателей Сербии. А. Петров немало лет преподавал в разных зарубежных университетах, в том числе США, Канады и Австралии.

Широкую известность и признание А. Петров получил как составитель и переводчик, а также автор вступительной и сопроводительных статей о поэтах в одной из самых полных изданных в Сербии антологий русской поэзии («Антология русской поэзии XVII-XX веков», 2011). Наделенный поэтическим даром, А. Петров с редким художественным вкусом отобрал для расширенного и дополненного издания «Антологии» (первое вышло в 1977 г.), наряду с известными поэтами и стихами, стихотворения малоизвестных авторов. Это значительно расширило представление читателя о русской лире XX в., ее богатстве и оригинальности.

В рецензируемом труде научные исследования автора органично сочетаются с его личными впечатлениями от общения с русскими поэтами и учеными. Это налагает отпечаток на гибридный характер книги, которая как целое все же выглядит органично, так как ее автор - ученый и поэт одновременно, и трудно сказать, кто же он, прежде всего. Целостность работе придают размышления о русской литературе, прежде всего поэзии и путях ее развития, которым отведено главное место как в исследованиях, так и воспоминаниях о встречах с русскими поэтами, переводчиками и учеными. Книга в полной мере отразила незаурядную творческую личность А. Петрова, его эрудицию и масштаб его собственного не ограниченного рамками конкретной научной школы понимания движения творческой мысли великих русских поэтов. Для российского читателя одинаково интересны его размышления о развитии русского стихосложения на протяжение трех столетий и воспоминания о встречах и разговорах о поэзии с выдающимися русскими учеными, писателями и переводчиками (Р. Якобсон, М. Бахтин, К.Ф. Тарановский, А. Вознесенский, И. Бродский др.).

Книга «Литературная Россия...» содержит избранные труды А. Петрова разных лет о русском формализме, об истории русской поэзии от былинного эпоса, Симеона Полоцкого до И. Бродского. Одной из главных проблем в исследованиях А. Петрова является проблема самобытности русской поэзии, отражения в ней национального видения мира, что автор обнаруживает еще в народной эпической поэзии, а затем выделяет как черту художественной индивидуальности в лирике XVIII-XXI вв. В статье «Русская идея в русской поэзии: Восток и Запад, “свое” и "чужое" в былинах» А. Петров останавливается на мотиве противостояния былинных героев киевского цикла - защитников родины - иноземным завоевателям и его художественной реализации. Подчеркивается патриотический пафос эпоса, кровная связь богатырей с отечеством и верой. «Герои былин не ставят своей целью распространять веру, особенно не огнем и мечом, как закон божий распространяли крестоносцы. Герои не были и завоевателями чужих земель, они защитники родины» (стр. 25), - приходит к выводу автор.

Большой научный интерес представляет раздел «Русская поэтическая традиция», содержащий статьи об особенностях эволюции русской поэзии, увиденной автором через развитие устойчивых мотивов, присутствующих в ней почти три века. Это мотивы, связанные с государственной символикой (образ двуглавого орла, «Медного всадника», Петербурга), образом родины («Тема России в мессианской перспективе»), библейскими мифами о сотворении мира, великом потопе 
и др. Их автор прослеживает лирике от С. Полоцкого и М. Ломоносова, А. Пушкина, до А. Блока, А. Ахматовой, Е. Евтушенко. Характерны они и для поэзии русской эмиграции. Такой подход к анализу русской поэзии в ее диахронии сформировался вследствие необходимости решения практической задачи: подбором авторов и текстов для антологии. Это всегда ставит вопрос о критерии, понимании того, «что такое поэзия и великая поэзия прежде всего» и «что есть поэзия одного народа или языка, одной эпохи или школы» (стр. 27) и как ее можно наиболее убедительным образом представить. А. Петров справедливо замечает, что составитель антологии, как и историк литературы, служат общей цели. Антология, по его мнению, представляет собой особый жанр, мерила которого «приспособлены не столько к отдельным произведениям, сколько к целому, идеальному порядку самой антологии» (стр. 29). Естественно, этот порядок не может быть абсолютно свободным от исторического контекста, времени, когда та или иная антология составляется. Недаром представленная картина русской поэзии вызывала бурную реакцию не только литераторов и литературоведов, но и властных особ. Кроме того, А. Петров рассматривает жанр антологии в движении, замечая, что эпоха Интернета неизбежно наложит на этот жанр свой отпечаток. Отдающий предпочтение свободному стиху, А. Петров проявляет интерес к этому типу поэзии и при составлении антологии, и при оценке путей развития современного русского стихосложения, и в разговорах и спорах о поэзии с Г. Сапгиром и И. Бродским. Последний, как известно, был сторонником рифмованного стиха.

Отдельное внимание уделено анализу культурно-исторической роли журнала «Русский архив» (1928-1937), который выходил в Белграде. Этот журнал был одним из важнейших печатных органов в русском зарубежье, прежде всего в Югославии, на страницах которого большое внимание уделялось литературе, и был адресован не только русским, но и сербским читателям, так как выходил на сербском языке. Ценность и убедительность суждениям А. Петрова придает тот факт, что он сам был (и продолжает оставаться) организатором и редактором нескольких литературных журналов, в том числе объединяющих читателей-эмигрантов (он редактор старейшего сербского журнала «Србобран» в США). Он в своих выводах равно опирается как на научный анализ, так и на практический опыт. При анализе роли и значения журнала «Русский архив» ученый сопоставляет его с аналогичными журналами русской эмиграции первой волны, в первую очередь с пражским журналом «Воля России» и парижскими «Современными записками». «Тем, что "Русский архив” в первую очередь обращался к “иностранному читателю”, он отличался от других журналов того времени. А иностранного читателя журнал искал в современном югославском общественном мнении, чтобы познакомить его с “истинной Россией”... во всем блеске ее гения» (стр. 189), - пишет автор. Журнал стал органом, который объединил вокруг себя «первоклассных интеллектуалов, ученых, специалистов в разных областях, писателей, деятелей искусства и журналистов; некоторые жили в Сербии и Югославии, а остальные присылали корреспонденции из Праги, Парижа и других европейских городов» (стр. 206). Этот журнал был важен также тем, что освещал литературную жизнь как в эмиграции, так и в России (статьи М. Слонима и др.). Кроме того, особое внимание уделено сотрудничеству в журнале М. Цветаевой, которая писала о русской художнице Наталье Гончаровой, Владимире Маяковском и Борисе Пастернаке, о Пушкине и современной русской поэзии. В свою очередь Н. Гончарова выступила автором текстов о создании декораций к балетам Стравинского. 
Плодотворным было сотрудничество с «Русским архивом» А. Ремизова (статьи о творчестве Пушкина, Толстого, Тургенева, Чехова, Блока, Горького, Замятина и др.), о чем, как заметил автор, «можно было бы написать отдельную монографию» (стр. 211). А. Петров проанализировал рубрики «Русского архива», подчеркнув значимость в определении качества литературной периодики, на первый взгляд, «второстепенных» материалов, которые отличаются высоким качеством. Он выделяет в этой связи рубрики «Обзора статей и материалов»: «Почти нет ни одной значительной русской книги, из любой области, опубликованной в России или в эмиграции, так же как и многих русских журналов и газет в период выхода "Русского архива", появление которых не сопровождалось критическим откликом или более обширной заметкой» (стр. 205). А. Петров высказал также интересные наблюдения над литературным журналом как особым жанром («Русский формализм и периодика»). В целом, изданная на русском языке книга А. Петрова, безусловно, относится к трудам, стимулирующим исследовательскую мысль.

Сведения об авторе:

Алла Геннадьевна Шешкен, доктор филол. наук

профессор

филологический факультет

МГУ имени М.В. Ломоносова
Alla Shesken,

Doctor of Philology

Professor

Philological Faculty

Lomonosov Moscow State University

asheshken@yandex.ru 